\title{
Öğrencilerin Cerrahi Hastalıkları Hemşireliği Yaz Stajı Dosyalarında Belirledikleri Hemşirelik Tanıları ve Girişimlerinin Değerlendirilmesi
}

\section{Evaluation of Nursing Diagnoses and Interventions Determined by Students in Surgical Diseases Nursing Summer Internship Files}

\author{
Nurgül Bölükbaş (iD) Burçin Irmak ${ }^{2}$ (iD) Gülay Bulut ${ }^{3}$ (D) Dilek Aydın Özdemir ${ }^{4}$ (iD) Hasret Yasemin Bayrak ${ }^{5}$ (iD \\ ${ }^{1}$ Ordu Üniversitesi Sağlık Bilimleri Fakültesi Hemşirelik Bölümü, Cerrahi Hastalıkları Hemşireliği Anabilim Dalı, Ordu, TÜRKIYE \\ ${ }^{2}$ Gazi Üniversitesi Sağlık Bilimleri Fakültesi Hemşirelik Bölümü Cerrahi Hastalıkları Hemşireliği Anabilim Dalı, Ankara, TÜRKIYYE \\ ${ }^{3}$ Korgan Devlet Hastanesi, Hemodiyaliz Ünitesi, Ordu, TÜRKIYE \\ ${ }^{4}$ Aybastı Devlet Hastanesi, Hemodiyaliz Ünitesi, Ordu, TÜRKIYE \\ ${ }^{5}$ Samsun Eğitim ve Araștırma Hastanesi Kadın Doğum ve Çocuk Hastanesi, Süt Çocuğu Kliniği, Samsun, TÜRKIYE \\ Geliş tarihi/ Date of receipt: 05/04/2020 Kabul tarihi/ Date of acceptance: 22/04/2020 \\ C Ordu University Faculty of Health Sciences, Department of Nursing, Turkey, Published online 30/04/2020
}

ÖZ

Amaç: Bu çalışma, hemşirelik ikinci sınıf öğrencilerinin cerrahi hastalıkları hemşireliği yaz stajı uygulamalarındaki hemşirelik tanıları ve girişimlerinin değerlendirilmesi amacıyla yapıldı.

Yöntem: Retrospektif ve tanımlayıcı tipte yapılan araştırmanın evrenini Karadeniz bölgesinde bir devlet üniversitesinin Sağlı Yüksekokulu'nda Cerrahi Hastalıkları Hemşireliği yaz stajını tamamlayan 108 öğrenci oluşturdu. Araştırmanın verileri Haziran-Eylül 2015 tarihleri arasında yaz stajı yapan öğrencilerin dosyalarından toplandı. Hemşirelik tanıları North American Nursing Diagnosis Association-I (NANDA-I) tanı listesine göre incelendi. Verilerin analizi bilgisayarda istatistik paket programı kullanılarak s1klık ve yüzdelik olarak yapıldı.

Bulgular: Araştırmada incelenen toplam 108 yaz staj dosyasında 216 hemşirelik tanısı incelenmiş ve 29 farklı hemşirelik tanısı belirlenmiştir. Tanılara yönelik 786 hemşirelik uygulaması ve 48 farklı hemşirelik girişimi saptanmıştır. Staj süresince öğrencilerin en fazla belirledikleri beş hemşirelik tanısı akut ağrı (\%25.9), enfeksiyon riski (\%18.5), anksiyete (\%9.7), uyku düzeninde bozulma (\%5.6) ve kanama riskidir (\%5.1). Hemşirelik tanılarına yönelik en fazla yapılan hemşirelik uygulamaları ise sırasıyla; hekim istemindeki analjezik ilaçların uygulanması (\%7.4), hastaya bilgi verilmesi (\%6.2), hastanın yaşamsal bulgularının takibi (\%5.7), hastaya pozisyon verilmesi (\%5.0) ve hastaya egzersiz yaptırılmasıdır (\%4.8).

Sonuç: Araştırma sonucunda öğrenciler tarafından konulan hemşirelik tanılarının ve yapılan girişimlerin sınırlı olduğu saptandı. Bu doğrultuda eğitim müfredatında ve klinik uygulamada hemşirelik sürecine ilişkin vaka tartışmalarının artırılması önerilebilir.

Anahtar Kelimeler: Öğrenci hemşire, hemşirelik tanısı, hemşirelik süreci, bakım planı

\section{ABSTRACT}

Objective: This study was carried out in order to determine the nursing diagnoses and implementations in surgical diseases nursing summer internship files of nursing students.

Methods: The population of the retrospective and descriptive study consisted of 108 students who completed the summer practice of Surgical Diseases Nursing at the School of Health of a public university in the Black Sea region. The data of the research were collected from the files of students who completed summer internship between June-September 2015. Nursing diagnoses were examined according to the North American Nursing Diagnosis Association-I (NANDA-I) diagnosis list. The data were evaluated in frequency and percentage using the descriptive statistics in the SPSS 18.0 package program on the computer.

Results: In the 108 summer internship files evaluated, 216 nursing diagnoses were examined and 29 different nursing diagnoses were determined. There were 786 nursing practices and 48 different nursing interventions for diagnoses. The most frequent five nursing diagnoses determined by the students during the internship are acute pain (25.9\%), risk of infection (18.5\%), anxiety (9.7\%), sleep disorders $(5.6 \%)$ and bleeding risk $(5.1 \%)$. The most frequent nursing interventions for nursing diagnoses are; the application of analgesic drugs at the physician's request (7.4\%), informing the patient $(6.2 \%)$, monitoring the vital signs of the patient $(5.7 \%)$, positioning the patient $(5.0 \%)$ and exercising the patient $(4.8 \%)$.

Conclusion: As a result of the research, it was determined that the nursing diagnoses and applications made by the students were limited. Accordingly, it can be suggested to increase the case discussions regarding the nursing process in the education curriculum and clinical practice.

Keywords: Nursing student, nursing diagnosis, nursing process, care plan

ORCID IDs of the authors: NB: 0000-0001-5684-8359, BI: 0000-0003-2168-1872, GB: 0000-0001-7016-8077, DAÖ:0000-0002-2473-6675,

HYB: 0000-0002-6218-5018

Sorumlu yazar/Corresponding author: Doc. Dr. Nurgül BÖLÜKBAS

Ordu Üniversitesi Sağlık Bilimleri Fakültesi, Cerrahi Hastalıklar Hemşireliği Anabilim Dalı, Ordu, TÜRKIYE,

e-posta/e-mail: nurbol 52@ hotmail.com

Bu çalışma, 28-29 Nisan 2016 tarihinde Eskişehir'de 15. Ulusal Hemşirelik Öğrenci Kongresi’nde poster bildiri olarak sunulmuştur.

Atıf/Citation: Bölükbaş N, Irmak B, Bulut G, Aydın Özdemir D, Bayrak HY. (2020). Öğrencilerin cerrahi hastalıkları hemşireliği yaz stajı dosyalarında belirledikleri hemşirelik tanıları ve girişimlerinin değerlendirilmesi. Ordu Üniversitesi Hemşirelik Çalışmaları Dergisi, 3(1), 1-9. DOI: $10.38108 /$ ouhcd.715689 


\section{Giriş}

Hemşirelik süreci, hemşireliği bilimsel bilgiye temellendiren ve bakımı organize ederek görünür hale getiren önemli bir araçtır. Sistematik bir yöntem olan hemşirelik süreci; tanılama, hemşirelik tanısı, planlama, uygulama ve değerlendirme olmak üzere birbirini takip eden beş aşamadan oluşmaktadır (Erdemir, 2012). Hemşirelik sürecinin kullanılmasının; bakımın sistematik hale getirilmesi, öncelikli girişimlerin belirlenmesi, bakımda sürekliliğin sağlanması, hasta ve hemşire arasındaki iletişimin güçlendirilmesi ve olası hataların önlenmesi gibi yararları vardır. Ayrıca hastaya verilen hemşirelik bakımının kayıt altına alınması yasal yönden de hemşireyi koruma altına almaktadır (Aksoy, 2012; Çalışkan ve Gülnar, 2019).

Günümüzde hemșirelik tanıları, girișimleri ve sonuçları sinıflama sistemleri ile açıklanmaktadır (Ay, 2008). Hemşirelik tanıları listesi ilk kez 1973 yılında Kuzey Amerika Hemşireler Birliği (North American Nursing Diagnosis Association [NANDA]) tarafindan yayınlanmıştır. $\mathrm{Bu}$ tanılar daha sonra evrensel standardizasyonu sağlamak için taksonomi haline getirilmiştir. NANDA-I hemşirelik tanılar1 taksonomisi Carpenito-Moyet tarafından bir kitap haline getirilmiş ve ülkemizde Erdemir tarafından çevirisi yapılarak "Hemşirelik Tanıları: El Kitabı" adıyla yayınlanmıştır (Erdemir, 2012). Hemşirelik sürecinin aşamalarının sınıflandırma sistemleri ile değerlendirilmesi hemşirelikte ortak bir dil oluşturmasının yanı sıra hastanın da kapsamlı değerlendirilmesini sağlamaktadır (Ay, 2008; Gençbaş ve Bebiş, 2017).

Hasta/sağlıklı birey ya da ailesinden kapsamlı olarak veri toplamak için kuramcılar tarafından çeşitli modeller geliştirilmiştir. $\mathrm{Bu}$ modellerden biri de Fonksiyonel Sağllk Örüntüleri (FSÖ) modelidir. FSÖ modeli; sağlı̆̆ algılama-sağlığın yönetim biçimi, beslenme-metabolik örüntü, aktivite-egzersiz örüntüsü, boşaltım/eliminasyon örüntüsü, uykudinlenme örüntüsü, bilişsel-algısal örüntü, kendini algılama örüntüsü, rol-ilişki örüntüsü, cinsellik-üreme örüntüsü, başetme-stres tolerans1, değer-inanç örüntüsü olmak üzere toplam 11 başlıktan oluşmaktadır (Türk, 2017). Günümüzde yaygın olarak kullanılan NANDAI, FSÖ modeline temellendirilmiştir (Erdemir, 2012). Bu model kolay öğrenilmesi, tüm hemşirelik uzmanlık alanlarında ve yaş gruplarında kullanılabilmesi nedeniyle yaygın olarak tercih edilmektedir (Türk, 2017).

Hemşirelik sürecinin temelleri hemşirelik eğitimi sırasında atılmaktadır. Öğrenci eğitiminde hemşirelik sürecinin kullanımı mesleki profesyonelliğin gelişmesine, mesleki kavramların ortaya çıkmasına, hasta bakımının kolay uygulanmasına katkı sağlar (Özveren ve ark., 2019). Hemşirelik modellerinin ve NANDA gibi sinıflandırma sistemlerinin eğitimde kullanılması hemşirelik öğrencilerine rehberlik etmektedir. Literatürde yurtdişında ve ülkemizde yapılan araştırmalarda öğrencilerin bakım planı hazırlamaya yönelik olumlu tutumları olduğu saptanmıştır (Ogunfowokan ve ark., 2013, Y1lmaz ve ark., 2015; Özveren ve ark., 2019). Ancak öğrenciler hemşirelik sürecini kullanırken çeşitli sorunlar yaşayabilmektedir. Keski ve Karadağ' in (2010) araştırmasında hemşirelik öğrencilerinin hemşirelik sürecinin uygulanmasında sorun yaşadıkları, bu sorunun en fazla hemşirelik tanısı belirleme ve veri toplama aşamalarında olduğu belirlenmiştir. Yılmaz ve ark. (2015) tarafindan yapılan bir çalışmada, öğrencilerin en fazla yaşadığı sorunun hemşirelik tanılarının belirlenmesinde yaşandığı saptanmıştır.

Mesleki yaşamda hemşirelik sürecini etkili ve doğru kullanmak için öğrenci hemşirelerin lisans eğitiminden itibaren klinik uygulamalarda hemşirelik sürecini doğru ve etkili kullanmaları gerekmektedir (Aksoy, 2012; Çalışkan ve Gülnar, 2019). Literatür incelendiğinde, cerrahi hastalıkları hemşireliği uygulamaları sırasında hemşirelik tanılarının incelendiği sınırlı sayıda çalışma olduğu saptanmıştır (Erden ve ark., 2018; Uysal ve ark., 2016; Aydın ve Akansel, 2013). Konuya ilişkin araştırmaların artması hem bilimsel literatüre katkı verecek hem de cerrahi hastalıkları hemşireliği eğitiminde yenilikler yapılmasına katkı sağlayacaktır.

$\mathrm{Bu}$ araştırma öğrencilerin yaz stajı dosyasındaki hemşirelik tanılarını ve 
girişimlerini belirlemek amacıyla retrospektif ve tanımlayıcı olarak yapıldı.

Araştırma Sorulart:

- Hemşirelik öğrencilerinin cerrahi hastalıkları hemşireliği yaz staj dosyalarında yer alan bakım planlarında belirledikleri hemşirelik tanıları nelerdir?

- Hemşirelik öğrencilerinin cerrahi hastalıkları hemşireliği yaz staj dosyalarında yer alan bakım planlarında hemşirelik tanılarına yönelik yaptıkları hemşirelik girişimleri nelerdir?

\section{Yöntem}

Retrospektif ve tanımlayıc1 tipte olan araştırmanın evrenini Karadeniz bölgesinde bir devlet üniversitesinin Sağlık Yüksekokulu'nda, 2014-2015 öğretim y1lı yaz döneminde Cerrahi Hastalıkları Hemşireliği stajını tamamlayan 108 hemşirelik 2. sınıf öğrencisi oluşturmuştur. Araştırmada örneklem seçimine gidilmemiş, yaz stajında bir cerrahi hastası için bakım planı hazırlayan ve yaz staj dosyasını teslim eden tüm öğrenciler araştırma kapsamına alınmıştır. Öğrencilerin tümü (108 öğrenci) yaz stajına devam etmiş ve yaz stajı dosyalarında bakım planı hazırlamışlardır.

Araştırmanın yürütüldüğü $\quad$ Sağlık Yüksekokulu Hemşirelik Bölümü 2. sinıf öğrencileri eğitim öğretim dönemini tamamladıktan sonra, yaz döneminde İç Hastalıkları Hemşireliği dersinden 10 iş günü ve Cerrahi Hastalıkları Hemşireliği dersinden 10 iş günü olmak üzere toplam 20 iş günü zorunlu staj yapmaktadır. Staj yapılan kurumlar en az 100 yatak kapasiteli olan eğitim ve araştırma hastaneleri, devlet hastaneleri veya özel hastaneler olabilmektedir.

Öğrenciler, staj uygulaması öncesinde Yüksekokul Yaz Staj Komisyonu tarafından hazırlanan staj dosyasını imza karşılığında teslim almaktadır. Staj dosyasi; yaz staj yönergesi, beceri listesi, hastane/servis tanıtım basamakları, günlük staj raporları, hasta tanılama formu, hemşirelik bakım planı, öğrenciye ve staj kurumuna yönelik bilgilerin yer aldığ1 toplam 44 sayfadan oluşmaktadır. Öğrenciler staj süresince her gün dosyadaki "Günlük Staj Raporu” bölümünü doldurmaktadır. Bu bölüm; kliniğin adı, tarih, klinikteki yatak sayısı, hasta sayısı, günlük çalışan hemşire sayısı, günlük yapılan hemşirelik girişimleri, her gün bir hastaya yönelik öğrenci hemşirenin yaptığı hemşirelik bakımı ve girişimlerini içermektedir. Ayrıca öğrenciler staj süresince bir cerrahi hastasına yönelik hemşirelik bakım planı hazırlamaktadır. Hasta verileri dosyada yer alan "Hasta Tanılama Formu" ile toplanmaktadır. Hasta Tanılama Formu, Gordon (1982) tarafindan geliştirilen Fonksiyonel Sağlı Örüntüleri (FSÖ) Modeli'ne göre düzenlenmiştir. Veriler doğrultusunda belirlenen hemşirelik tanıları; belirti ve bulgular, etiyoloji, hemşirelik tanısı, amaç, planlama, uygulama ve değerlendirme bölümlerinden oluşan hemşirelik bakım planına kaydedilmektedir. Öğrenciler hemşirelik süreci ile ilgili birinci sınıf öğretim müfredatında yer alan Hemşireliğe Giriş ve Hemşirelik Esasları derslerinin içeriğinde teorik ve vaka incelemesi ile ilgili eğitim almaktadırlar. Öğrenciler staj dosyalarını Yüksekokulun öğrenci işleri birimine staj sonunda teslim etmektedir. $\mathrm{Bu}$ dosyalar ilgili anabilim dalı öğretim elemanları tarafından değerlendirilmektedir.

\section{Verilerin Toplanması}

Öğrenciler Haziran-Eylül 2015 yaz döneminde, iki hafta süresince haftada beş gün olmak üzere toplam 10 gün cerrahi kliniklerde staj yapmıştır. Araştırma verileri 1-15 Mart 2016 tarihleri arasında dersin sorumlu öğretim elemanları tarafindan yaz staj dosyaları incelenerek toplanmıştır. Öğrencilerin staj yaptığı cerrahi birimler; genel cerrahi, beyin ve sinir cerrahisi, üroloji, plastik ve rekonstrüktif cerrahi, kalp ve damar cerrahisi, ortopedi ve travmatoloji, kulak-burun-boğaz hastalıkları cerrahisi, göğüs cerrahisi, acil servis ve cerrahi yoğun bakım üniteleridir. Öğrenciler her staj günü sonunda uyguladıkları girişimleri günlük olarak dosyaya raporlandırmıştır. Ayrıca staj süresince ameliyat öncesi ya da ameliyat sonrası dönemdeki bir cerrahi hastasının hemşirelik bakım planını dosyaya rapor etmişlerdir. Staj dosyalarından; öğrencilerin cinsiyetleri, uygulama yaptıkları hastane türü, uygulama yapılan cerrahi klinik, bakım verdikleri hastaların hemşirelik tanıları ve tanıya yönelik hemşirelik girişimleri, tanıya yönelik amaca 
ulaşılıp ulaşılmadığı değerlendirilmiştir. Veriler NANDA-I hemşirelik tanılarına göre incelenmiştir (Erdemir, 2012).

Araştırmaya başlamadan önce Sağlik Yüksekokulu Müdürlügü’nden yazılı izin alınmıştır.

\section{Verilerin Analizi}

Araştırma verileri bilgisayar ortamına aktarıld1ktan sonra IBM Statistical Package For Social Science (SPSS) for Windows 18.0 paket programı ile analiz edilmiştir. Verilerin analizinde tanımlayıcı istatistikler (sayı, yüzde ve sıklık) kullanılmıştır.

\section{Bulgular}

Araştırmada toplam 108 öğrencisinin yaz staj dosyası değerlendirilmiştir. Öğrencilerin $\% 73.1$ 'i kadın ve \%26.9'u erkektir. Öğrencilerin yaz stajı uygulamalarını yaptıkları sağlık kuruluşları; devlet hastanesi (\%78.7), eğitim ve araştırma hastanesi (\%20.4), özel hastane $(\% 0.9)$ olmuştur. Öğrencilerin staj uygulaması yaptıkları cerrahi birimler; genel cerrahi (\%50.9), beyin ve sinir cerrahi (\%12.0), üroloji (\%9.3), ortopedi ve travmatoloji (\%7.4), göğüs cerrahi (\%5.6), kulak burun boğaz hastalıkları cerrahi (\%4.6), kalp ve damar cerrahi (\%3.7), acil servis (\%3.7), cerrahi yoğun bakım üniteleri $(\% 1.8)$ ile plastik ve rekonstrüktif cerrahi $(\% 0.9)$ kliniğidir.

Tablo 1'de öğrencilerin Gordon'un FSÖ Modeline göre hastalarda belirledikleri NANDA-I hemşirelik tanılarının dağılımları yer almaktadır. Incelenen 108 staj dosyası içerisinde toplamda 216 hemşirelik tanısı değerlendirilmiş ve 29 farklı NANDA-I hemşirelik tanısı belirlenmiștir. Bu hemşirelik tanılarının 20'si mevcut hemşirelik tanısı ve 9'u olası (risk) hemșirelik tanısıdır. Öğrencilerin en fazla hemşirelik tanısı belirlediği FSÖ alanı beslenme-metabolik örüntüdür. Öğrenci hemşirelerin en fazla kullandıkları beş NANDA-I hemşirelik tanısı sırasıyla akut ağrı (\%25.9), enfeksiyon riski (\%18.5), anksiyete (\%9.7), uyku düzeninde bozulma (\%5.6) ve kanama riski (\%5.1) olarak belirlenmiştir.

Öğrencilerin en az kullanıldıkları hemşirelik tanıları ise; yutma güçlüğü, bireysel baş etmede etkisizlik, rahatlıkta (konforda) bozulma, üriner boşaltımda bozulma, deri bütünlügüünde bozulma riski ve periferal nörovasküler disfonksiyon riski olarak saptanmıştır. Araştırmada öğrenci dosyalarında FSÖ modelinin üç örüntüsüne ilişkin (rol ve ilişki, cinsellik-üreme, değer-inançlar) hemşirelik tanısının yer almadığı belirlenmiştir (Tablo 1).

Staj dosyalarında yer alan 29 NANDA-I hemşirelik tanısına yönelik toplam 786 hemşirelik uygulaması değerlendirilmiş ve 48 farklı hemşirelik uygulaması olduğu belirlenmiştir. Öğrenciler her bir hemşirelik tanısına yönelik en az 3, en fazla 10 hemşirelik girişimi yapmıştır. Hemşirelik tanılarına yönelik en fazla yapılan beş hemşirelik girişimi; "hekim isteminde yer alan analjezik ilaç uygulanır" (\%7.3), "hastaya hastalığı/yapılan işlem hakkında bilgi verilir" (\%6.2), "hastanın yaşamsal bulguları takip edilir" (\%5.7), "hastaya uygun pozisyon verilir" (\%4.9) ve "hastaya ROM (range of motion) egzersizleri yaptırılıı" (\%4.8) olmuştur. Öğrencilerin hemşirelik girişimleri içerisinde en az belirtilen ifade "hasta mahremiyetine özen gösterilir" olmuştur (\%0.1), (Tablo 2). Ayrıca bakım planlarındaki değerlendirme bölümü incelendiğinde öğrencilerin \%89.8'inin hemşirelik tanılarında belirledikleri amaçlara ulaştıkları tespit edilmiştir.

\section{Tartışma}

Hemşirelik tanıları hemşirelik mesleğini görünür hale getirmektedir. $\mathrm{Bu}$ nedenle hemşirelik öğrencilerinin hemşirelik sürecinin önemli bir parçası olan hemşirelik tanılarını belirleyebilmesi ve hemşirelik uygulamalarını planlayabilmesi oldukça önemlidir. $\mathrm{Bu}$ çalışmada bir Sağlık Yüksekokulu hemşirelik ikinci sınıf ögrencilerinin cerrahi hastalıkları hemşireliği yaz staj dosyalarında yer alan NANDA-I hemşirelik tanıları ve girişimleri belirlenmiştir. Araştırmamızda öğrencilerin en s1k belirledikleri hemşirelik tanıları akut ağrı, enfeksiyon riski, anksiyete, uyku düzeninde bozulma ve kanama riskidir (Tablo 1). 
Tablo 1. Öğrencilerin Gordon'un Fonksiyonel Sağlık Örüntüsü Modeline Göre Hastalarda Belirledikleri NANDA-I Hemşirelik Tanılarının Dağılımları $(n=216)$

\begin{tabular}{|c|c|c|c|}
\hline $\begin{array}{l}\text { FSÖ Modeli Veri } \\
\text { Toplama } \\
\text { Alanlari* }\end{array}$ & NANDA-I Hemşirelik Tanıları & $\mathbf{n}$ & $\%$ \\
\hline $\begin{array}{l}\text { Sağlığı Algılama- } \\
\text { Sağlığın } \\
\text { Yönetimi }\end{array}$ & Düşme riski & 2 & 0.9 \\
\hline \multirow{11}{*}{$\begin{array}{l}\text { Beslenme- } \\
\text { Metabolik }\end{array}$} & Enfeksiyon riski & 40 & 18.5 \\
\hline & Bulantı & 5 & 2.3 \\
\hline & Sıv1-elektrolit fazlalığ 1 & 4 & 1.9 \\
\hline & Sıv1-elektrolit eksikliği & 4 & 1.9 \\
\hline & Vücut sıcaklığında dengesizlik riski & 3 & 1.4 \\
\hline & Beslenmede dengesizlik: gereksinimden fazla & 2 & 0.9 \\
\hline & $\begin{array}{l}\text { Beslenmede dengesizlik: gereksinimden fazla } \\
\text { beslenme potansiyeli }\end{array}$ & 2 & 0.9 \\
\hline & Beslenmede dengesizlik: gereksinimden az & 2 & 0.9 \\
\hline & Yutma güçlüğü & 1 & 0.5 \\
\hline & Deri bütünlüğünde bozulma riski & 1 & 0.5 \\
\hline & Rahatlikta (konforda) bozulma & 1 & 0.5 \\
\hline \multirow[t]{2}{*}{ Boşaltım } & Konstipasyon riski & 4 & 1.9 \\
\hline & Üriner boşaltımda bozulma & 1 & 0.5 \\
\hline \multirow[t]{8}{*}{ Aktivite-Egzersiz } & Kanama riski & 11 & 5.1 \\
\hline & Fiziksel harekette bozulma & 10 & 4.6 \\
\hline & Doku bütünlüğünde bozulma & 5 & 2.3 \\
\hline & Gaz alışverişinde bozulma & 5 & 2.3 \\
\hline & Tromboemboli riski & 5 & 2.3 \\
\hline & Aktivite intoleransı & 3 & 1.4 \\
\hline & Öz-bakım eksikliği & 2 & 0.9 \\
\hline & Periferal nörovasküler disfonksiyon riski & 1 & 0.5 \\
\hline Uyku-Dinlenme & Uyku düzeninde bozulma & 12 & 5.6 \\
\hline \multirow[t]{2}{*}{ Bilişsel-Algısal } & Akut ağrı & 56 & 25.9 \\
\hline & Bilgi eksikliği & 6 & 2.8 \\
\hline $\begin{array}{l}\text { Kendini } \\
\text { Algılama }\end{array}$ & Beden imajında bozulma & 3 & 1.4 \\
\hline \multirow{3}{*}{$\begin{array}{l}\text { Başetme-Stres } \\
\text { Toleransı }\end{array}$} & Anksiyete & 21 & 9.7 \\
\hline & Korku & 3 & 1.4 \\
\hline & Bireysel başetmede etkisizlik & 1 & 0.5 \\
\hline \multicolumn{2}{|l|}{ Toplam } & 216 & 100 \\
\hline
\end{tabular}

*Ögrenciler rol-ilişkei, cinsellik-üreme ve değer-inançörüntülerine ilişkin hemsirelik tanusı belirtmediği için tabloda yer almamaktadir. 
Tablo 2. Öğrencilerin Belirledikleri Hemşirelik Girişimlerinin Dağılımları ( $\mathrm{n}=786)$

\begin{tabular}{|c|c|c|}
\hline Hemşirelik Uygulamaları & $\mathbf{n}$ & $\%$ \\
\hline 1. Hekim istemindeki analjezik ilaçlar uygulanır & 58 & 7.4 \\
\hline 2. Hastaya yapılan işlemler hakkında bilgi verilir & 49 & 6.2 \\
\hline 3. Hastanın yaşamsal bulguları takip edilir & 45 & 5.7 \\
\hline 4. Hastaya uygun pozisyon verilir & 39 & 5.0 \\
\hline 5. Hastaya ROM (range of motion) egzersizleri yaptırilır & 38 & 4.8 \\
\hline 6. Hastalığı hakkında hasta ve/veya ailesine bilgi verilir & 36 & 4.6 \\
\hline 7. Hastanın bakımında aseptik ilkelere uyulur & 35 & 4.1 \\
\hline 8. Hastanın ağrısı değerlendirilir & 32 & 3.7 \\
\hline 9. Hastanın diyeti diyetisyen işbirliği ile düzenlenir & 29 & 3.4 \\
\hline 10. Hastaya farmakolojik olmayan yöntemler uygulanır & 27 & 3.3 \\
\hline 11. Hastanın mobilizasyonu sağlanır & 26 & 3.2 \\
\hline 12. Hastada enfeksiyon belirti ve bulguları hastada izlenir & 25 & 2.9 \\
\hline 13. Hastanın dikkati başka yöne çekilir & 23 & 2.8 \\
\hline 14. Hastaya derin solunum ve öksürük egzersizleri yaptırılır & 22 & 2.5 \\
\hline 15. Hastanın çevre güvenliği sağlanır & 20 & 7.4 \\
\hline 16. Hastanın yeterli sıvı alımı sağlanır & 19 & 2.4 \\
\hline 17. Hastanın yara yeri olası komplikasyonlar yönünden kontrol edilir & 19 & 2.4 \\
\hline 18. Hastaya el hijyeni konusunda eğitim verilir & 18 & 2.3 \\
\hline 19. Hasta odasına ziyaretçi kabulü sınırlandırılır & 15 & 1.9 \\
\hline 20. Hastaya emosyonel destek sağlanır & 15 & 1.9 \\
\hline 21. Hastanın istirahati/dinlenmesi sağlanır & 14 & 1.8 \\
\hline 22. Hastaya sıcak ya da soğuk uygulama yapılır & 13 & 1.7 \\
\hline 23. Hasta ameliyat öncesi ve sonrası dönemde takip edilir & 12 & 1.5 \\
\hline 24. Hastanın uyku saatleri düzenlenir & 12 & 1.5 \\
\hline 25. Hasta odasının havalandırılması ve temizliği sağlanır & 12 & 1.5 \\
\hline 26. Hasta odasının sessiz ve sakin olması sağlanır & 11 & 1.4 \\
\hline 27. Hasta kanama belirti ve bulguları yönünden izlenir & 11 & 1.4 \\
\hline 28. Hastanın beslenmesine yardımcı olunur & 11 & 1.4 \\
\hline 29. Hastanın uyku saatlerinde hasta odasına giriş çıkış sınırlandırılır & 11 & 1.4 \\
\hline 30. Hastaya yardımcı araç-gereç (walker, baston gibi) kullanımında yardım edilir & 9 & 1.1 \\
\hline 31. Hastanın yara yeri pansumanı yapılır & 9 & 1.1 \\
\hline 32. Hastaya oksijen tedavisi uygulanır & 7 & 0.9 \\
\hline 33. Hastanın laboratuvar bulguları değerlendirilir & 6 & 0.8 \\
\hline 34. Hasta yatak istirahatine alınır & 6 & 0.5 \\
\hline 35. Hastaya hekim istemindeki antibiyotik ilaçları verilir & 6 & 0.5 \\
\hline 36. Hastanın aldığı-çıkardığı sıvıların izlemi yapılır & 5 & 0.5 \\
\hline 37. Hastada bacak elevasyonu sağlanır & 4 & 0.5 \\
\hline 38. Hastaya hekim istemindeki sedatif ilaçlar verilir & 4 & 0.5 \\
\hline 39. Hastanın dolaşım takibi (nörovasküler değerlendirme) yapılır & 4 & 0.5 \\
\hline 40. Hastanın günlük kilo takibi yapılır & 4 & 0.6 \\
\hline 41. Hastanın bağırsak sesleri değerlendirilir & 4 & 0.5 \\
\hline 42. Hastanın cildi (renk, turgor, nemlilik vb yönünden) değerlendirilir & 4 & 0.5 \\
\hline 43. Hastayla etkili başetme stratejileri geliştirilir & 4 & 0.5 \\
\hline 44. Hekim istemindeki antiemetik ilaçları uygulanır & 3 & 0.4 \\
\hline 45. Hastaya postüral drenaj uygulanır & 3 & 0.4 \\
\hline 46. Hasta odasına yonca figürü asılır & 3 & 0.4 \\
\hline 47. Hasta şok belirti ve bulguları yönünden takip edilir & 3 & 0.4 \\
\hline 48. Hasta mahremiyetine özen gösterilir & 1 & 0.1 \\
\hline Toplam & 786 & 100.0 \\
\hline
\end{tabular}


Kore'de yapılan bir araştırmada hemşirelik öğrencilerinin cerrahi birimlerde en s1k kullandığı beş hemşirelik tanısı sırasıyla akut ağr1, hipertermi, konstipasyon, bilgi eksikliği ve doku bütünlüğünde bozulmadır (Noh ve Lee, 2015). İtalya'da yapilan retrospektif bir çalışmada öğrencilerin en fazla belirlediği tanılar hareketlilikte bozulma, kişisel hijyen eksikliği ve cilt bütünlüğünün bozulmasına ilişkindir (Palese ve ark., 2009). Erden ve ark. (2018) tarafindan yapılan bir araştırmada hemşirelik öğrencilerinin cerrahi kliniklerde en sık belirledikleri hemşirelik tanıları sırasıyla enfeksiyon riski, ağrı, anksiyete, deri bütünlügünde bozulma ve uyku düzeninde bozukluktur. Aydın ve Akansel'in (2013) çalışmasında hemşirelik ikinci sınıf öğrencileri yaz stajında en fazla enfeksiyon riski, ağrı, aktivite intoleransı, anksiyete, beden gereksiniminden az beslenme ve konstipasyon tanılarını belirlemiştir. Hemşirelik ikinci sınıf öğrencileriyle yapılan bir başka çalışmada ise öğrenciler tarafindan en fazla enfeksiyon riski, uyku örüntüsünde rahatsızlık, akut ağrı, anksiyete ve vasküler travma riski tanıları belirlenmiştir (Uysal ve ark., 2016). İç hastalıkları ve cerrahi hastalıkları hemşireliği dersi alan ikinci sınıf öğrencileri ile yapılan bir araştırmada en fazla enfeksiyon riski, beslenme örüntüsünde değişim ve solunum fonksiyonlarında değişim tanıları belirlenmiştir (Özer ve Kuzu, 2006). Yapılan başka bir araştırmada hemşirelik öğrencilerinin en fazla anksiyete tanısını kullandığı belirtilmiştir (Mankan ve ark., 2014). Ayan'ın (2012) yaptığı çalışmada öğrencilerin en sık kullandıkları NANDA-I hemşirelik tanıları enfeksiyon riski, anksiyete ve deri bütünlüğünde bozulmadır. $\mathrm{Bu}$ sonuç hemşirelik öğrencilerinin hastalarında benzer hemşirelik tanılarını belirlediği ve hemşirelik tanılarının çoğunun hastaların fiziksel sorunlarına yönelik olduğunu göstermektedir. Öğrenciler cerrahi girişime bağlı komplikasyonları (kanama riski, enfeksiyon riski gibi), hastanın sözel ifadesine dayanan (akut ağrı) ya da gözlenebilen (uyku düzeninde bozulma) durumları daha kolay belirleyebilmektedir. Araştırma sonuçları literatüre benzerlik göstermektedir.
Araştırmamızda öğrencilerin en az kullanıldıkları hemşirelik tanıları yutma güçlügü̈, bireysel baş etmede etkisizlik, rahatlikta (konforda) bozulma, üriner boşaltımda bozulma, deri bütünlügünde bozulma riski ve periferal nörovasküler disfonksiyon riskidir. Doğan'ın (2017) hemşirelik ikinci sınıf öğrencileri ile yaptığı çalışmada da doku perfüzyonunda yetersizlik ve periferik nörovasküler disfonksiyon riski tanılarının öğrenciler tarafından belirlenmesinin güç olduğu belirtilmiştir. Palese ve ark. (2009)'ın araştırmasında öğrencilerin en az belirlediği hemşirelik tanıları korku, emzirmenin kesintiye uğraması ve spritüel distres (manevi sıkınt)' dir.

Araştırmamızdaki öğrenciler rol-ilişki, inanç-değerler, cinsellik ve üreme konularında hemşirelik tanısı belirtmemiștir. Özer ve Kuzu'nun (2006) çalışmasında öğrenciler değerler-inanç ve cinsellik-üreme ile ilgili hemşirelik tanısı belirleyememiştir. Zaybak ve ark. (2018) araştırmasında da FSÖ modeline göre en az hemşirelik tanısı belirtilen örüntü cinsellik ve üreme olarak saptanmıștır. Yılmaz ve ark. (2015) araștırmasında öğrencilerin kendilerini yeterli hissetmedikleri üç FSÖ modeli örüntüsünün; cinsellik-üreme, başetmestres toleransı ve değer-inanç olduğu belirlenmiştir. Yılmaz ve ark. (2019) çalışmasında ise hemşirelik öğrencilerinin benlik kavramı, cinsellik ve üreme, rol ve ilişki örüntüsüne yönelik veri toplamakta güçlük yaşadığı saptanmıştır. Erden ve arkadaşlarının (2018) çalışmasında da ikinci sınıf öğrencilerin cerrahi hastalıkları hemșireliği dersinde daha az tespit ettikleri tanılar cinsel yaşamda değişiklik, sosyal izolasyon ve korku gibi daha soyut kavramlardan oluştuğu belirlenmiştir. Ülkemizde yapılan çalışmalarda hemşirelik öğrencilerinin bu alanlara yönelik veri toplama ve tanı koymada sıkıntı yaşadıklarını ve bakım planlarında ilgili tanılara yer vermedikleri belirlenmiştir. Hemşirelik öğrencileri, bakım verdikleri hastalar ile cinsel sorunlar hakkında konuşmaktan rahatsı olduğunu ve utandıklarını belirtmişlerdir (Aydın ve Akansel, 2003; Özer ve Kuzu, 2006; Türk, 2017). Araştırma sonuçları literatürle benzerlik 
göstermektedir. Ayrıca araştırma kapsamındaki hemşirelik öğrencilerinin henüz kadın sağlığı ve hastalıkları ile ruh sağlığı ve hastalıkları hemşireliğine ilişkin ders almadıkları için bu sorunları belirlemede yetersiz oldukları düşünülebilir.

Araştırmamızda hemşirelik tanılarına yönelik en fazla yapılan hemşirelik girişimleri, hekim istemindeki analjezik ilaçların uygulanması, hastaya işlem hakkında bilgi verilmesi, hastanın yaşamsal bulgularının takibi, hastaya pozisyon verilmesi ve egzersiz yaptırılmasıdır. Çalışmamıza benzer olarak Noh ve Lee (2015)'nin araştırmasında da hemşirelik öğrencilerinin cerrahi birimlerde en s1k yaptıkları hemşirelik girişimlerinin ağrı yönetimi, yaşamsal bulguların takip edilmesi, pozisyon verme, emosyonel destek ve gevşeme terapisi olduğu belirtilmiştir. Keski ve Karadağ'ın (2010) hemşirelik son sinıf öğrencileriyle yaptığı çalışmada; öğrencilerin hemşirelik sürecine ilişkin bilgi eksiklikleri olduğu ve hemşirelik süreci aşamalarında en yüksek oranda değerlendirme, en düşük ise planlama-uygulama aşamalarına ilişsin sorulara doğru cevap verdikleri belirlenmiştir. Başka bir çalışmada ise, hemşirelik tanılarının yetersiz objektif ve subjektif verilere dayanılarak belirlendiği, tıbbi tanı, semptom ve bulguların hemşirelik tanısı olarak ifade edildiği belirtilmiştir (Uysal ve ark., 2016).

\section{Sonuç ve Öneriler}

Araştırmada, hemşirelik öğrencilerinin sınırlı sayıda hemşirelik tanısı belirlediği, bu tanıların çoğunun hastaların fiziksel gereksinimlerine yönelik olduğu belirlenmiştir. Öğrencilerin FSÖ modeline göre rol ve ilişki, cinsellik ve üreme, inanç ve değerler örüntülerinde hemşirelik tanısı belirleyemedikleri saptanmıştır. Öğrencilerin hemşirelik uygulamalarında hastaları biyopsikososyal yönden desteklemek için yeterli girişimde bulunmadıkları belirlenmiştir.

$\mathrm{Bu}$ bulgular doğrultusunda;

- Öğrenci hemşirelerin hemşirelik sürecine ilişkin farkındalıklarının artırılması,

- Hemşirelik sürecine ilişkin örnek vaka çalışmalarının müfredatta ve klinik uygulamada artırılması,

- Öğrencilerin bakım planı hazırlama sürecinde yaşadıkları güçlüklerin ve sınırlılıkların belirlenerek öğretim elemanları ve hemşireler tarafından desteklenmesi,

- Konuyla ilgili daha büyük örneklem gruplarıyla farklı çalışmalar yapılması önerilmektedir.

\section{Araştırmanın Sınırlılıkları}

Araştırma tek bir kurumda gerçekleştiği ve veriler yalnızca bir eğitim-öğretim yılına ilişkin cerrahi hastalıkları hemşireliği yaz staj dosyalarının incelemesiyle elde edildiği için genellenebilirliği sınırlıdır. Araştırmadan elde edilen sonuçlar yalnızca araştırmaya katılan öğrenci grubuna genellenebilir.

\section{Teșekkür}

Çalışmaya katılan hemşirelik öğrencilerine teşekkür ederiz.

Araştırmanın Etik Yönü/ Ethics Committee Approval: Araştırmanın yapıldığı Sağlık Yüksekokulu Müdürlüğü'nden yazılı izin alınmıştır. Dosyalar incelenmeden önce öğrenciler bilgilendirilmiş ve sözel onam alınmıştır. Dosyaların incelenmesi dersin sorumlu öğretim elemanları tarafından gerçekleştirilmiştir.

Hakem/Peer-review: D1ş hakem değerlendirmesi.

Yazar Katkısı/Author Contributions: Fikir/kavram: NB, BI; Tasarım: NB, BI; Danışmanlık: NB; Veri toplama: NB, BI; Veri işleme: GB, DAÖ, HYB; Analiz ve/veya Yorum: BI, GB, DAÖ, HYB; Kaynak tarama: BI; Makalenin Yazımı: NB, BI; Eleştirel inceleme: NB.

Çıkar çatışması/Conflict of interest: Araştırmada herhangi bir çıkar çatışması yoktur.

Finansal Destek/Financial Disclosure: $\mathrm{Bu}$ çalışma herhangi bir kurum ya da kuruluş tarafından desteklenmemiştir.

Çalışma Literatüre Ne Kattı?

- Araştırma hemşirelik öğrencilerinin yaz staj dosyalarındaki bakım planlarında belirledikleri hemşirelik tanılarının ve uygulamalarının sınırlı olduğunu ortaya koymuştur.

- Öğrencilerin hemşirelik tanılarında daha çok hastaların fiziksel gereksinimlerini belirledikleri ve psikososyal gereksinimleri belirlemekte sinırlı oldukları belirlenmiştir.

- Öğrencilerin rol-ilişki, cinsellik-üreme, inanç ve değerlerle ilişkili hemşirelik tanısı belirlemedikleri saptanmıştır. 


\section{Kaynaklar}

Aksoy G. (2012). Cerrahi ve Cerrahi Hemşireliği. Aksoy G., Kanan N., Akyolcu N, Editörler. Cerrahi Hemşireliği I, Bölüm: 1, İstanbul: Nobel Tip Kitabevi:27-36, ISBN: 978-975-420-886-3

Ay F. (2008). Uluslararası alanda kullanilan hemşirelik tanıları ve uygulamaları sınıflandırma sistemleri. Türkiye Klinikleri, 28(4), 555-561.

Ayan S. (2012). Hemşirelik öğrencilerinin NANDA-I hemşirelik tanılarını belirleme yetkinliğinin saptanması. Yayınlanmamış Yüksek Lisans Tezi, İstanbul Üniversitesi Sağl1k Bilimleri Enstitüsü, İstanbul, Türkiye.

Aydin N, Akansel N. (2013). Determination of accuracy of nursing diagnoses used by nursing students in their nursing care plans. International Journal of Caring Sciences, 6(2), 252-257.

Çalışkan N, Gülnar E. (2019). Cerrahi Hastasının Bakım Süreci. Karadağ M., Bulut H., Editörler. Cerrahi Hemşireliği Kavram Haritası ve Akış Şemalı, 1. Cilt, Bölüm: 21, Ankara: Vize Yayıncılık: 1037-1084, ISBN: 978-605-927866-69.

Doğan M.D. (2017). Nursing diagnoses determined by second year students. Journal of Patient Care, 3(1), 1-3.

Erden S, Deniz S, Arslan S, Yurtseven Ş. (2018). Hemşirelik öğrencilerinin cerrahi hastalıkları hemşireliği dersi uygulamalarında hemşirelik tanılarını belirleme düzeylerinin incelenmesi. Van Tip Dergisi, 25(2), 108-112.

Erdemir F. (2012) Hemşirelik tanıları el kitabı. 13. Bask1, Ankara, Nobel T1p Kitabevi, s.1-790.

Gençbaş D., Bebiş H. (2017). Uluslararası standart sistem ile olușturulan hemșirelik bakım planı örneği. Başkent Üniversitesi Sağlık Bilimleri Fakültesi Dergisi-BÜSBID, 2(1) 79-96.

Gordon, M. (1982). Functional health patterns. Nursing Diagnosis rocess and application. New York: Mc. Graw Hill Book Comp, 685-702.

Keski Ç, Karadağ A. (2010). Hemşirelik son sınıf öğrencilerinin hemşirelik süreci hakkındaki bilgi düzeylerinin incelenmesi. Hemşirelikte Araştırma Geliştirme Dergisi, 12(1),41-52.

Mankan T, Narci I, Kurtaran D. (2014). Hemşirelik öğrencilerinin NANDA-I hemşirelik tanılarına ilișkin görüşlerinin belirlenmesi. 13. Ulusal Hemşirelik Öğrencileri Kongresi, Bildiri Kitabı: s.118. 1-3 Mayıs 2014, Trabzon, Türkiye.
Noh HK, Lee E. (2015). Relationships among NANDA-I diagnoses, nursing outcomes classification, and nursing interventions classification by nursing students for patients in medical-surgical units in Korea. International Journal of Nursing Knowledge, 26 (1):43-51. https://doi.org/10.1111/2047-3095.12044

Ogunfowokan AA, Oluwatosin AO, Olajubu AO, Alao OA, Faremi AF. (2013). Student nurses' perceived use of NANDA-I nursing diagnoses in the community setting. International journal of nursing knowledge, 24(1), 37-43.

Ozveren H, Ozden D, Gulnar E. (2019). Determination of nursing students' perception states in nursing diagnosis. International Journal of Caring Sciences, 12(2), 1049-1055.

Özer FG, Kuzu N. (2006). Öğrencilerin bakım planlarında hemşirelik süreci ve NANDA tanılarını kullanma durumları. Ege Üniversitesi Hemşirelik Fakültesi Dergisi, 22(1), 69-80.

Palese A, Silvestre DD, Valoppi G, Tomietto M. (2009). A 10-year retrospective study of teaching nursing diagnosis to baccalaureate students in Italy. International Journal of Nursing Knowledge, 20(2), 64-75. doi: 10.1111/j.1744618X.2009.01117.x

Türk G. (2017). Marjory Gordon: Fonksiyonel Sağlık Örüntüleri Modeli. Karadağ A., Çalışkan N., Baykara Z.G. Editörler. Hemşirelik Teorileri ve Modelleri, Bölüm: 24, İstanbul: Akademi Basın ve Yayınc1lık: 604-619, ISBN: 978-60583287-8-5

Uysal N, Arslan GG, Yilmaz İ, Alp FY. (2016). Hemşirelik ikinci sınıf öğrencilerinin bakım planlarındaki hemşirelik tanıları ve verilerin analizi. Celal Bayar Üniversitesi Sağlık Bilimleri Enstitüsü Dergisi, 3(1), 139-143.

Yılmaz AA, Gençer E, Seçkin Ç, Yılmaz H, Güven KT, Gözütok S. (2019). Hemşirelik öğrencilerinin hemşirelik sürecinin veri toplama aşamasına ilişkin görüşleri ve yaşadıkları güçlükler. Anadolu Hemşirelik ve Sağlık Bilimleri Dergisi, 22(4), 231-239.

Y1lmaz FT, Sabanciogullari S, Aldemir K. (2015). The opinions of nursing students regarding the nursing process and their levels of proficiency in Turkey. Journal of caring sciences, 4(4), 265275.

Zaybak A, Özdemir H, Erol A, Ismailoğlu EG. (2018). An exploration of nursing students' clinical decision-making process. International Journal of Nursing Knowledge, 29(4), 210-216. doi: 10.1111/2047-3095.12179. 